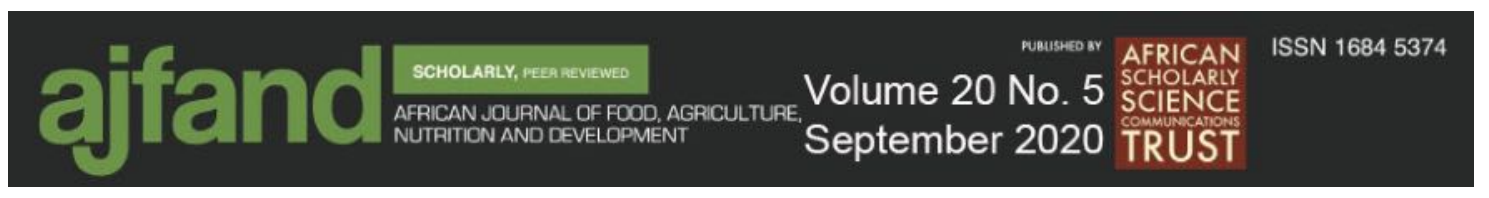

Afr. J. Food Agric. Nutr. Dev. 2020; 20(5): 16563-16584 https://doi.org/10.18697/ajfand.93.19960

PROTEIN AND AMINO ACID COMPOSITION OF DIFFERENT QUINOA

(CHENOPODIUM QUINOA WILLD) CULTIVARS GROWN UNDER FIELD

CONDITIONS IN ETHIOPIA, KENYA, UGANDA, AND ZAMBIA

\title{
Lung'aho $\mathbf{M}^{1^{*}}$, Fenta $\mathrm{AB}^{2}$, Wanderi $\mathrm{S}^{3}$, Otim $\mathrm{A}^{4}$, Mwaba $C^{5}$, F Nyakundi ${ }^{1}$ and MM Abang ${ }^{6}$
}

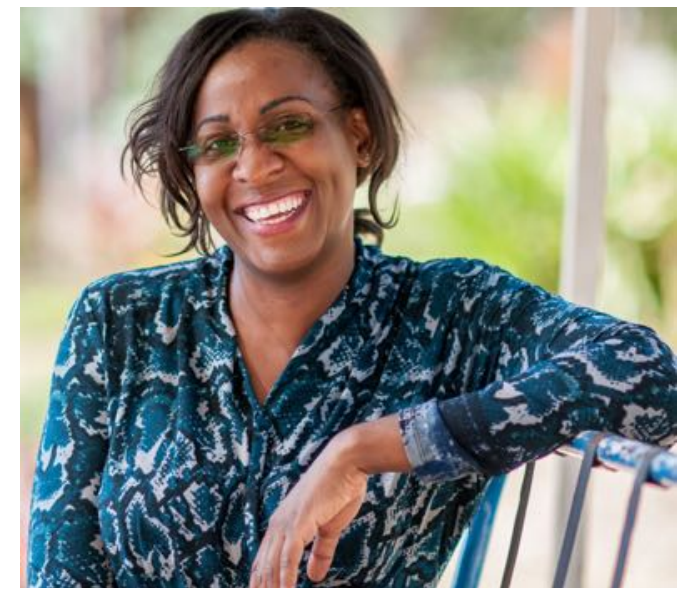

Mercy Lung'aho

*Correspondence author email: m.lungaho@,cgiar.org

${ }^{1}$ International Center for Tropical Agriculture (CIAT), P.O. Box 823-00621, Nairobi, Kenya

${ }^{2}$ Ethiopian Institute of Agricultural Research (EIAR), Melkassa Agricultural Research Centre, P.O. Box 436, Adama, Ethiopia

${ }^{3}$ Kenya Agricultural and Livestock Research Organization (KARLO), P.O. Box 27, 60100, Embu, Kenya

${ }^{4}$ National Crops Resources Research Institute (NaCCRI), P.O. Box 7084, Kampala, Uganda

${ }^{5}$ Zambia Agricultural Research Institute (ZARI) Private Bag 7, Chilanga

${ }^{6}$ Food and Agriculture Organization of the United Nations (FAO) Sub-regional Office for Southern Africa, P.O. Box 3730 Harare, Zimbabwe 


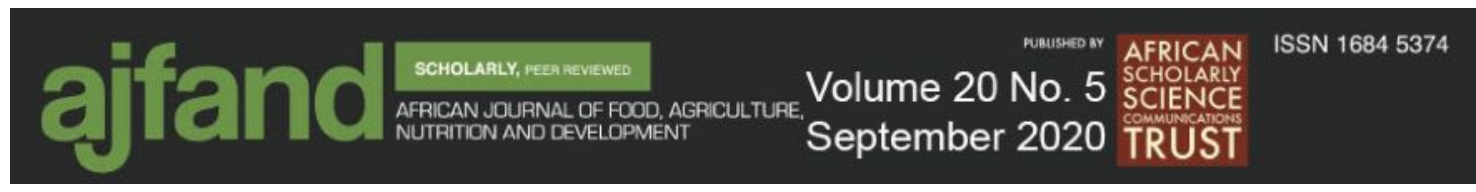

\begin{abstract}
Protein-energy malnutrition (PEM) remains a public health concern in most developing nations. In Africa, PEM can be attributed to monotonous diets based on cereals, roots, and tubers, with little or no protein of animal origin. Diversifying cropping systems to include protein dense pseudo-cereals such as Quinoa (Chenopodium quinoa Willd.) could help provide more protein in the diet of vulnerable populations. Quinoa is a crop with potential for biodiversification because it has a high nutritional value; however, it is underutilized in Africa, and information about the nutritional quality of the grain grown in contrasting environments is limited. Within the framework of FAO's commemoration of 2013 as the 'The International Year of the Quinoa' (IYQ), a Technical Cooperation Programme (TCP) project was developed with some African countries to assess the capacity of quinoa to adapt to different agro-ecological regions and the nutritional quality of the resulting grain. For this study, we evaluated the protein content and amino acid profile of three genotypes of quinoa that had been grown under diverse altitudes, soil, and climate conditions in Ethiopia, Kenya, Uganda, and Zambia. The mean protein content $(\mathrm{g} / 100 \mathrm{~g})$ of Kancolla, Titicaca and BBR varieties grown in Africa ranged from $14.33 \pm 0.20$ to $17.61 \pm 0.55,14.23 \pm 0.25$ to $16.65 \pm 0.55$, and $13.13 \pm 0.2$ to $16.23 \pm 0.49$, respectively. On the other hand, the protein content $(\mathrm{g} / 100 \mathrm{~g})$ of Kancolla, Titicaca, and BBR seeds grown in Peru was $13.80 \pm 0.10,17.43 \pm 0.31$, and $17.07 \pm 0.11$, respectively. The Kancolla variety [grown in Ethiopia and Kenya] had a significantly higher protein content than that obtained from Peru $[P<0.001]$. Regarding the profile of essential amino acids, Quinoa is essentially richer in methionine than most cereals. Levels of methionine were lower in the seeds grown in Africa compared to those from Peru $[P<$ $0.001]$. In terms of environmental influences, the protein content was relatively higher in quinoa seeds grown in high-altitude areas, where soils have a low $\mathrm{pH}$ and high nitrogen content. We conclude that Quinoa can be introduced to Africa, especially to high altitudes and warm regions where the soil has a low $\mathrm{pH}$ and high nitrogen content. The crop would be ideal for diversifying local diets.
\end{abstract}

Key words: Africa, Agro-ecology, Chenopodium quinoa, protein, amino acid content, biodiversity, diets 


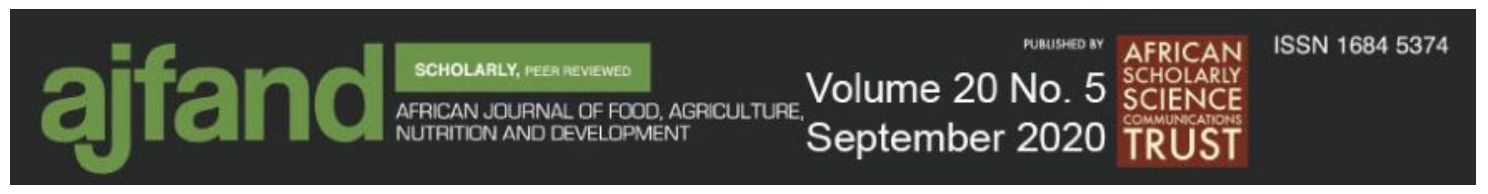

\section{INTRODUCTION}

Protein-energy malnutrition (PEM) remains a public health concern in most developing nations. A recent review concluded that, although the 'protein gap' waned during the 1970 s, contemporary studies have challenged the assumption that children in low-income countries are receiving sufficient dietary protein [1]. For example, one study used the World Health Organization's (WHO) Global Database on Child Growth - which covers $87 \%$ of the total population of children under five years old in developing countries - to describe the worldwide distribution of PEM. The study showed that more than one-third of the children in this age group are affected by PEM globally [2].

Another study reported varying types and severities of hearing impairment in children with moderate and severe PEM [3]. Also, an evaluation of six studies to test for synergism and elevated mortality in mild to moderate malnutrition demonstrated that about $56 \%$ of child deaths in developing countries could be attributed to PEM [4]. The extent of PEM and its consequences on morbidity, disability, and mortality call for a renewed awareness of the importance of protein in the diets of vulnerable populations in developing countries.

In Africa, diet is often based on at least one of three staple food groups: cereals, roots, and tubers, with little or no protein of animal origin [4]. Some of the most widely consumed grains in Africa are maize, rice, sorghum, and millet, while cassava, yams, sweet potatoes and potatoes, constitute the most prevalent roots and tubers. Dependence on these food groups has resulted in a 'nutrition gap,' a disconnect between which foods are grown and available, and which foods are needed to sustain optimal nutrition outcomes [5]. Also, the persistence of staple grain fundamentalism in agricultural policy, coupled with the rate at which biodiversity has been lost, hampers incentives for the diversification of production systems [6]. This limits the extent to which vulnerable populations can diversify their diets, and calls for a paradigm shift which under food systems and diets are reexamined and redesigned from a public health perspective [7]. This approach may include shifting focus to neglected and underutilized species that are essential components of agrobiodiversity [8].

The Food and Agriculture Organization (FAO) of the United Nations has been at the forefront of promoting underutilized crops to improve biodiversity, food security, and nutrition outcomes. Quinoa, for example, has been singled out as a food with high nutritional value, impressive biodiversity, and an important role to play in the achievement of food and nutrition security worldwide. Indeed, FAO commemorated 2013 as the 'The International Year of the Quinoa' (IYQ), the superfood of the Andes [9].

In addition to its nutritional qualities, quinoa is also considered a multipurpose crop [10]. Originally grown in the Andean region, its importance has led to it being cultivated in other countries, especially the mountainous regions of Africa [11]. Initial research results from quinoa cultivation in Kenya indicate high seed quality and a yield level comparable to that obtained in the Andes, making it a prime candidate for crop diversification in similar African countries [11, 12]. Several countries, including Peru, Bolivia, Chile, 


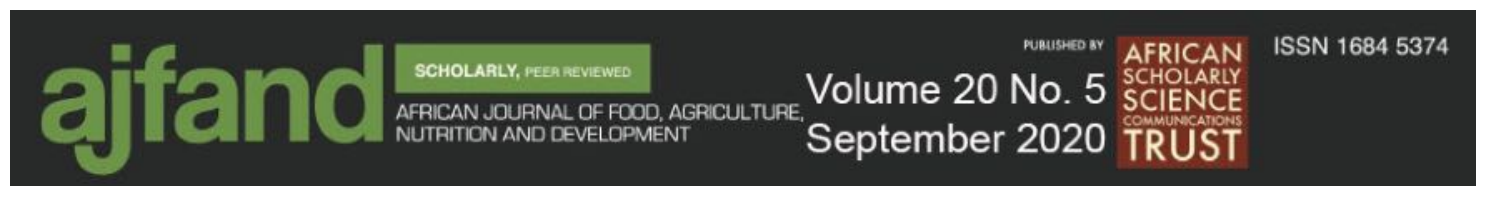

Ecuador, Colombia, Argentina, India, Mexico, Egypt, the USA, Canada, Italy, Greece, and Spain, have already expanded the production of quinoa for human nutrition $[13,14]$.

Quinoa is comparable, and at times superior, to other cereals and pseudo-cereals, which increases its potential to impact diet diversification and nutrition outcomes in Africa. It has high levels of bioactive compounds such as daidzein and genistein, dietary fibre, total phenolics, antioxidant activity, fatty acids, carotenoid, and tocopherol/tocotrienol [15, $16,17,18,19,20]$. Quinoa also has a higher fatty acid composition than amaranth and of most essential amino acids [especially lysine] than wheat flour [10, 21]. The total phenol content and antioxidant activity are also higher in quinoa than in wheat and amaranth [22, 23]. Quinoa has also been shown to have a higher protein and fat content, and a more balanced amino acid composition than major cereals, including maize and rice $[14,24]$.

However, studies have also shown that the growth of quinoa and its nutrient profile may vary according to location and environmental factors. For example, variations in seed yield, total protein content, and amino acid composition among cultivars grown in Andean highlands and Argentinean Northwest were attributed to environmental and climatic factors [13]. Significant nutritional differences and antioxidant capacity were also found among six quinoa seeds grown under three different climatic conditions in Chile $[14,24]$. There also exist genotype-specific responses to high salinity among Chilean lowland genotypes [25].

The agricultural and nutritional versatility of quinoa can leverage food security and better diets for populations in Africa. Consequently, a project building on the IYQ was developed for seven African countries to assess the capacity of quinoa to adapt to different agroecological regions and the nutritional properties of the resulting grain. This project also built on earlier efforts in the late 1990s and early 2000 s for quinoa promotion in Ethiopia, Mali, and Kenya [26]. This analysis is part of agronomic studies carried out in Ethiopia, Kenya, Uganda, and Zambia to determine the best-suited cultivation and production techniques for the quinoa crop and farming systems involved [9]. Therefore, the goal of this study was to evaluate the protein content and amino acid profile of quinoa seeds (Chenopodium quinoa Willd) under the diverse altitude, soil, and climatic conditions of the four African countries listed above. Analyzing the adaptability of quinoa and the resulting nutritional profile in these systems will be useful in the development of national and regional strategies to introduce quinoa in the region sustainably, from evaluation, selection of suitable varieties, and utilization, to processing into food products and marketing.

\section{MATERIALS AND METHODS}

\section{Study areas and their environmental and soil characteristics}

Ethiopia, Kenya, Uganda and Zambia were the four countries that participated in the agronomic trials for quinoa. In each country, at least one site was established based on the agroecological zoning of the land. The respective national agricultural research centers managed the trials. In total, the experiments were planted in 12 environments across the four countries [9]. 


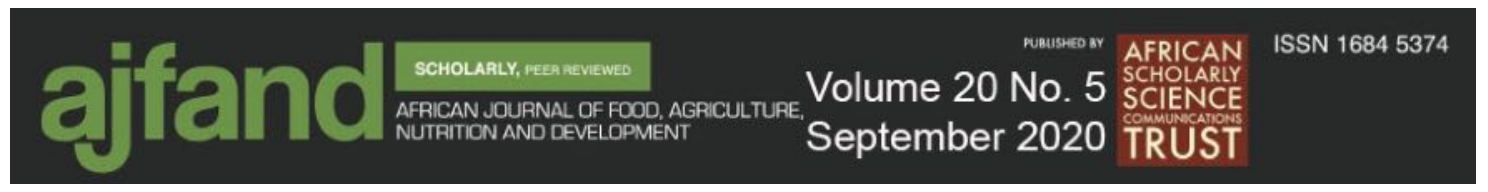

\section{Plant materials}

Seeds of three genotypes of quinoa were used: Kancolla variety, supplied by Instituto Nacional de Innovación Agraria (INIA), Peru; Brightest Brilliant Rainbow (BBR) variety, provided by Lilongwe University of Agriculture and Natural Resources (LUANAR), Malawi; and Titicaca variety, supplied by LUANAR, Malawi.

\section{Experimental design of field trials}

As previously published [9], the field trial design was a Randomized Complete Block Design (RCBD) with three replications and a plot size of $2 \times 2 \mathrm{~m}^{2}$ (four-row plots). A mixture of $5 \mathrm{~g}$ of seed and $5 \mathrm{~g}$ of sand (1:1) was planted per plot using the drilling planting method in all sites.

After germination, the plants were thinned to achieve a spacing of $50 \mathrm{~cm}$ between rows and $10 \mathrm{~cm}$ between plants (a total of 80 plants). The net plot was considered as the two center rows per plot and resulted in approximately 40 plants. Spacing between plots was 0.5-1 $\mathrm{m}$ and 1-1.5 $\mathrm{m}$ between replicates.

To ensure that agronomic, watering and nutritional constraints did not impact the crop during development, irrigation was conducted in areas where rain fed conditions were absent. Irrigation was mainly practiced in Zambia and Kenya.

\section{Protein and amino acid analysis}

Total protein was determined using the method prescribed by the DIN Standards Committee [27]. The nitrogen content was determined with the combustion method using a DUMATHERM ${ }^{\circledR}$ analyzer (C. Gerhardt GmGbH \& Co. KG, Königswinter, Germany) according to the Dumas method [28]. A total of $100 \mathrm{mg}$ of the crushed sample was weighed in triplicate. The universal protein-to-nitrogen conversion factor of 6.25 was used for the calculation of the protein content expressed in grams per $100 \mathrm{~g}$ of sample.

\section{LC-MS/MS analysis of amino acids}

Amino acids were analyzed as previously described [29]. The analysis was carried out on a Perkin Elmer Series 200 HPLC system, connected to an API 2000 (AB Sciex) triple quadruple mass spectrometer equipped with electrospray ionization (ESI) probe. A $10 \mu 1$ aliquot was injected through an autosampler. The separation was achieved using a C18 column (Perkin Elmer, $220 \mathrm{~mm} \times 4.6 \mathrm{~mm} \times 5 \mathrm{~mm}$ ). The mobile phase was composed of (A) water with $0.1 \%(\mathrm{v} / \mathrm{v})$ formic acid and (B) methanol/water $(50: 50) 0.1 \%(\mathrm{v} / \mathrm{v})$ formic acid with flow rate $1 \mathrm{~mL} / \mathrm{min}$; gradient $0-1.0 \mathrm{~min} / 2 \%$ (v/v) $\mathrm{B}, 1-10 \mathrm{~min} / 2-80 \%$ (v/v) $\mathrm{B}$, $10-12 \mathrm{~min} / 80 \%$ (v/v) B, $12-13 \mathrm{~min} / 80-2 \%$ (v/v) B and $12-18 \mathrm{~min} / 2 \%(\mathrm{v} / \mathrm{v}) \mathrm{B}$. The ion source voltage was $5500 \mathrm{~V}$; temperature was $500{ }^{\circ} \mathrm{C}$, nebulizer gas was $207 \mathrm{kPa}$, and heater gas $379 \mathrm{kPa}$.

\section{Protein quality}

The protein content of Kancolla, Titicaca, and BBR across the five countries was further compared using $\mathrm{FAO} / \mathrm{WHO}$, and $\mathrm{FAO} / \mathrm{WHO} / \mathrm{UNU}$ suggested patterns for the amino acid requirements of children and adults, respectively [30,31]. The amino acid score was further determined, as previously described [32]. 


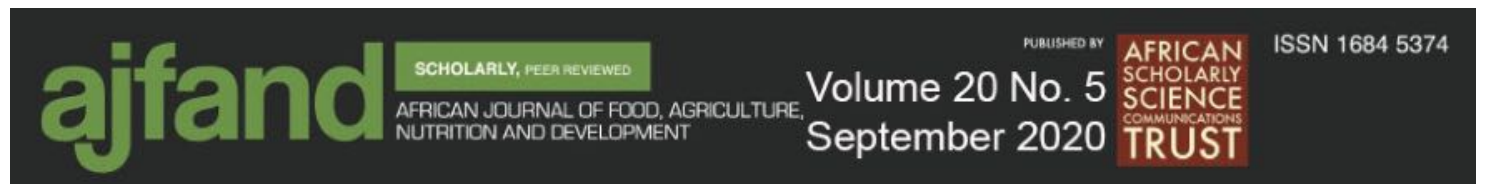

\section{Soil and Ecology data}

Data on soil ecology and characteristics of the agro-ecologies is from the larger agronomic studies as published [9].

\section{Data analysis}

The means, standard deviations, and analysis of variance (ANOVA) of the protein content and amino acid profiles of quinoa, as well as the soil characteristics of different research sites, were analyzed using Genstat (15, VSN International Ltd, Hemel Hempstead, United Kingdom). Statistically significant means were separated using Duncan's mean separation technique. Principal component analysis (PCA) of an environment/genotype $\times$ trait matrix, containing standardized trait data, was analyzed through a biplot constructed by plotting the symmetrically scaled principal component 1 (PC1) scores against the principal component 2 (PC2) scores using InfoStat ${ }^{\circledR}$ statistical software (version 2016, Facultad de Ciencias Agropecuarias, Universidad Nacional de Cordoba, Argentina).

\section{RESULTS AND DISCUSSION}

\section{The protein content of quinoa varieties grown in Peru and Africa}

The protein content of three varieties of quinoa seeds (BBR, Kancolla, and Titicaca) grown in the four African countries are shown in Fig. 1. The seeds were compared with original seeds grown in Peru. The moisture content of all the analysed seeds was 14\%.

The mean protein content $(\mathrm{g} / 100 \mathrm{~g}$, on dry weight basis) of Kancolla, Titicaca and BBR seeds grown in Africa ranged from $14.33 \pm 0.20$ to $17.61 \pm 0.55,14.23 \pm 0.25$ to 16.65 \pm 0.55 , and $13.13 \pm 0.2$ to $16.23 \pm 0.49$, respectively. On the other hand, the protein content $(\mathrm{g} / 100 \mathrm{~g})$ of Kancolla, Titicaca, and BBR seeds grown in Peru was $13.80 \pm 0.10,17.43$ \pm 0.31 , and $17.07 \pm 0.11$, respectively. Overall, significant $(P<0.001)$ differences in the protein content of each variety of quinoa seeds were observed, resulting from the country where the quinoa grew. The protein content in the Kancolla variety, grown in Africa, was significantly $(P<0.001)$ higher than the variety grown in Peru, except for Zambia. In the case of Titicaca and BBR varieties, the protein content of the seeds grown in Africa were significantly $(P<0.001)$ lower than those grown in Peru.

Differences in protein content among quinoa genotypes have been associated with nitrogen content in the soil [33]. Although few studies have been carried out on quinoa seeds in Africa, laboratory analysis carried out in Morocco and Egypt showed that the protein of quinoa ranges between $12.5 \%-14.1 \mathrm{~g} / 100 \mathrm{~g}[34,35]$. Protein content in quinoa generally ranges from $13.8 \mathrm{~g} / 100 \mathrm{~g}-16.5 \mathrm{~g} / 100 \mathrm{~g}$, with an average of $15 \mathrm{~g} / 100 \mathrm{~g}$ [36]. The protein content of quinoa grown in Ethiopia, Kenya, Uganda, and Zambia was within this range, which clearly shows that, although geographical variations exist, quinoa remains a better source of protein than most of the common cereals in the region (Figure 1). For example, the protein content of maize grain (Zea mays var. indurate Sturt) Hybrid 614, grown in Kenya, ranges from 6.9-11.6g/100g [37]. 

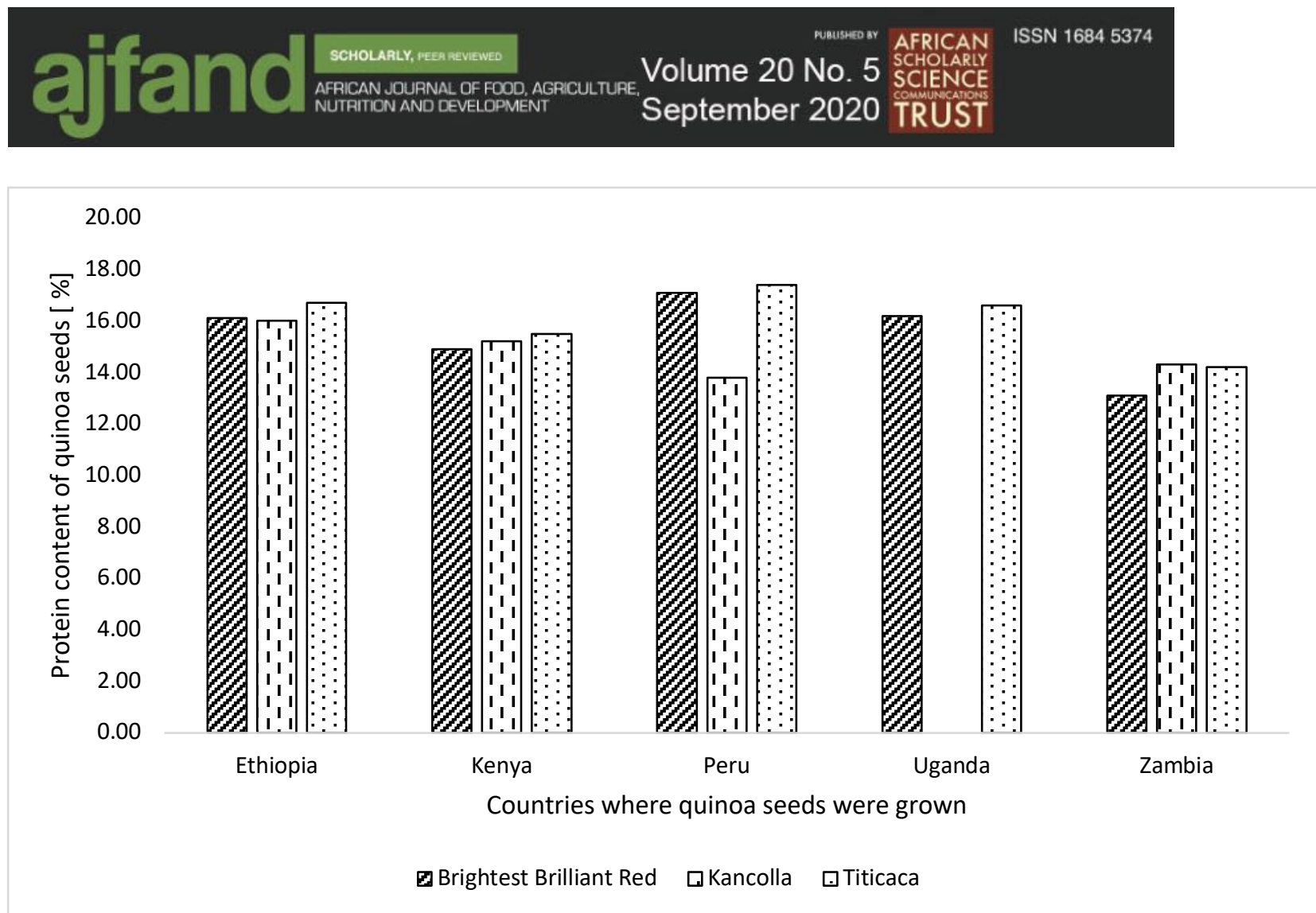

Figure 1: The protein content (dry weight basis) of quinoa seeds grown in Africa and Peru

Protein is required for normal body growth and function, and inadequate protein intake can contribute to impaired growth and suboptimal health in humans [38]. Replacing cereals with quinoa can potentially overcome these health effects. A previous study showed the protein content of Kancolla obtained from Peru to be low (13.4g/100g) [39]. However, the protein content can be remarkably high when the same variety is grown in the various countries in Africa.

\section{Amino acid profile of quinoa varieties grown in Peru and Africa}

An assessment of the non-essential amino acids in quinoa seeds showed the least difference, in terms of amino acid profile, in Kancolla and Titicaca. Tyrosine content of Kancolla and BBR seeds grown in Peru was lower than in African countries $(P<0.001)$ (Table 1). Levels of aspartic acid, serine, and glutamic acid were higher in BBR grown in Peru than in African countries $(P=0.01)$. In contrast, the amino acids of Kancolla did not differ among the African countries $(P=0.23)$. Proline, tyrosine, and arginine in Titicaca were significantly higher in Uganda than in the other three African countries $(P$ $<0.001)$. Serine was lowest in Uganda BBR, and arginine was lowest in Kenyan BBR $(P=0.02)$.

The profile of essential amino acids in the quinoa varieties varied greatly, unlike the nonessential amino acid profile (Table 2). In the Kancolla variety grown in Peru, the content of essential amino acids was statistically the same across the African countries $(P=0.33)$ in the study. In the Titicaca variety grown in Peru, valine, methionine, and phenylalanine were higher than in most of the African countries $(P<0.001)$. Threonine and methionine in BBR grown in Peru were higher than in the respective African countries $(P<0.001)$. 


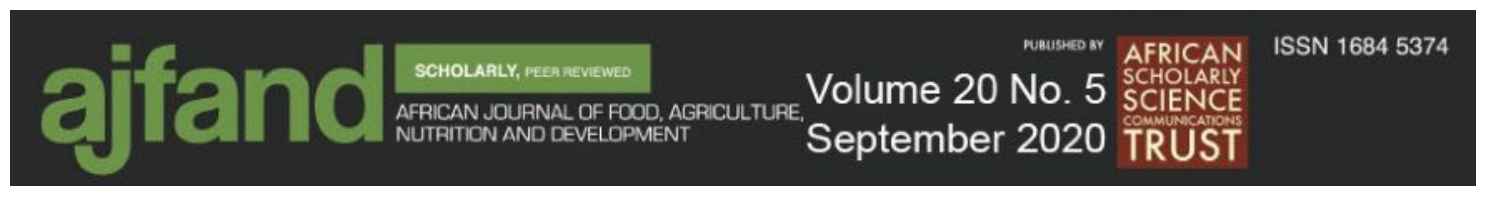

Isoleucine and leucine were higher in Zambia than the other African countries in BBR $(P=0.01)$. Methionine and lysine were lower in Zambia and Uganda, respectively, than in the other African countries $(P=0.03)$.

The results show that methionine, an essential amino acid, was particularly low across the quinoa genotypes (Tables 1 and 2). Essential amino acids cannot be synthesized by humans relative to their needs for maintenance, growth, development, and health and must be obtained through diet. Conversely, non-essential amino acids are those that can be synthesized in adequate amounts to meet requirements [40]. Nevertheless, amino acids are necessary for the survival, growth, development, reproduction, and health of all organisms, including humans [40]. Methionine and lysine are essential amino acids, and usually the most limiting amino acids in plant-derived diets [41]. As a result, vulnerable populations from developing countries, whose diet is significantly derived from plants, suffer from particular deficiencies in these two essential amino acids [42]. Despite these differences, it is not expected that quinoa seeds grown in Africa will have an impact on the contribution of methionine to nutrition in the region, provided consumption is high enough. Quinoa is essentially richer in methionine than most cereals [43]. The same may also be said of phenylalanine, another essential amino acid. It was found that phenylalanine was one of the most abundant amino acids in pseudo-cereals [44].

A balanced pattern of essential amino acids is one of the main features of quinoa [45]. The essential amino acid composition of quinoa, presented in Table 2, was compared to suggested patterns of amino acids and for adults and children [30, 32]. It was observed that the amino acid pattern of quinoa was above the requirements for all the amino acids, apart from methionine and phenylalanine, which were below the requirements in most countries. Given that the content of most amino acids [in particular lysine, which is limited in cereals] was above the requirements, it can be determined that quinoa has either adequate or high contents of essential amino acids for both children and adults [45].

Furthermore, maize, which is the primary source of energy for populations in Africa, is usually low in protein and amino acids. The low amino acid content in the blood serum, which can be associated with diets low in protein quality, has been shown to cause stunting in children [46]. The results in Table 2 further demonstrate the potential of quinoa to alleviate stunted growth in Africa by providing high protein quality diets. In Table 3, methionine was identified as the first limiting amino acid in quinoa grown in most countries. These results concur with previous reports which state that methionine is limiting in quinoa and amaranth, as well as other plant-derived products $[47,48]$.

The effect of genotype and environment (soil conditions, climate, and altitude) on protein content and amino acid profile of quinoa seeds - a case of three study sites

The three sites had a high elevation, each at least 1,100 $\mathrm{m}$ above sea level. Although the rainfall patterns varied from site to site, the site of Mbarara was both the driest and hottest. The soil analysis data shows that the soil characteristics differed in all the studied parameters, apart from phosphorus, aluminum, and manganese (Table 4). The soil in Mount Makulu was more saline and had a higher conductivity at $25^{\circ} \mathrm{C}$. It also contained more potassium, calcium, magnesium, and sodium. The soils in Namulonge, however, 


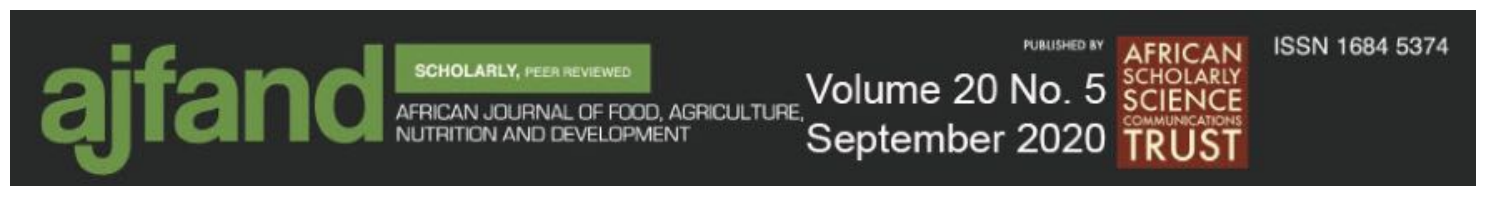

were more acidic. They also contained higher amounts of organic matter, total nitrogen, and calcium to magnesium $(\mathrm{Ca}: \mathrm{Mg})$ ratio. Soil parameters had been analyzed in triplicate as recommended [49].

Table 5 shows the protein content and amino acid profile of quinoa seeds grown in Uganda (Mbarara and Namulonge trial sites) and Zambia (Mount Makulu). The protein content in the three varieties was lowest in quinoa grown at the Mount Makulu trial site in Zambia $(P<0.001)$. For the Titicaca and BBR varieties, the non-essential amino acids and essential amino acids were highest in varieties grown at Namulonge $(P<0.05)$.

Results from the principal component analysis (PCA) applied to standardized data of all variables (protein content, amino acid profile, and soil characteristics) are summarized in a biplot (Fig. 2). The first two principal components (PC) of the analysis explained $87.5 \%$ of the total variation of the standardized variable data. This percentage is slightly higher than in a similar study in which $82.9 \%$ of the total variation in data was explained [49]. The biplot data from the sites in Uganda and Zambia are distributed on the left and right sides from the central axis of PC1, respectively. Furthermore, data from the Namulonge and Mbarara trial sites in Uganda is distributed on the top and bottom side from the central axis on PC2, respectively. Thus, the relationship among variables [identifiable by black crosses] and quinoa/research site (identifiable by black circles) positively correlated in each quadrant of the biplot. This correlation, which is an indication of a direct influence of the environment on the quinoa genotype traits, was, therefore, present when the variables and the genotypes/research site were in a similar quadrant.

The biplot analysis established that the environment in Uganda resulted in an improved nutritional profile of the three varieties of quinoa. Furthermore, soil $\mathrm{pH}$ significantly influenced the protein content of the seeds, whereby soil with a high $\mathrm{pH}$ corresponded with low protein content (Fig. 2). Similar results have been reported in other crops, such as beans [50]. Although it has been shown that quinoa is highly tolerant to soil with a high $\mathrm{pH}$, these results indicate that growing quinoa in such an environment may be detrimental to the availability of proteins and amino acids [51].

However, nitrogen content in the soil greatly increases the protein content of seeds [52]. Given that the soil in Mount Makulu had low nitrogen content (Table 4), the biplot analysis (Figure 1) clearly explains why quinoa seeds grown at Mount Makulu had a significantly lower amount of protein and amino acids than those grown in Uganda (Table 5). It is plausible that growing quinoa in nitrogen-deficient soils lowers its protein and nitrogen content.

With regards to the difference in nutritional profile in quinoa seeds grown in Uganda, the effects of altitude are evident, as protein content positively correlated with high altitude (Figure 2). This can be explained by the study results, specifically where Mbarara had a higher altitude than the three sites (Table 4). Having originated from the mountainous Andes region, it is plausible that quinoa is well suited for high elevations. These results further show the importance of such adaptation to the role of quinoa in nutrition. As previously stated, these types of results provide useful information for planning genetic 


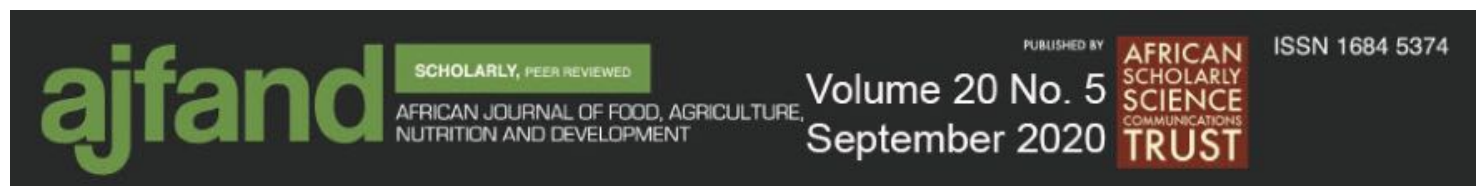

and productive improvements in quinoa, focused on its nutritional and functional properties in different environments [49].

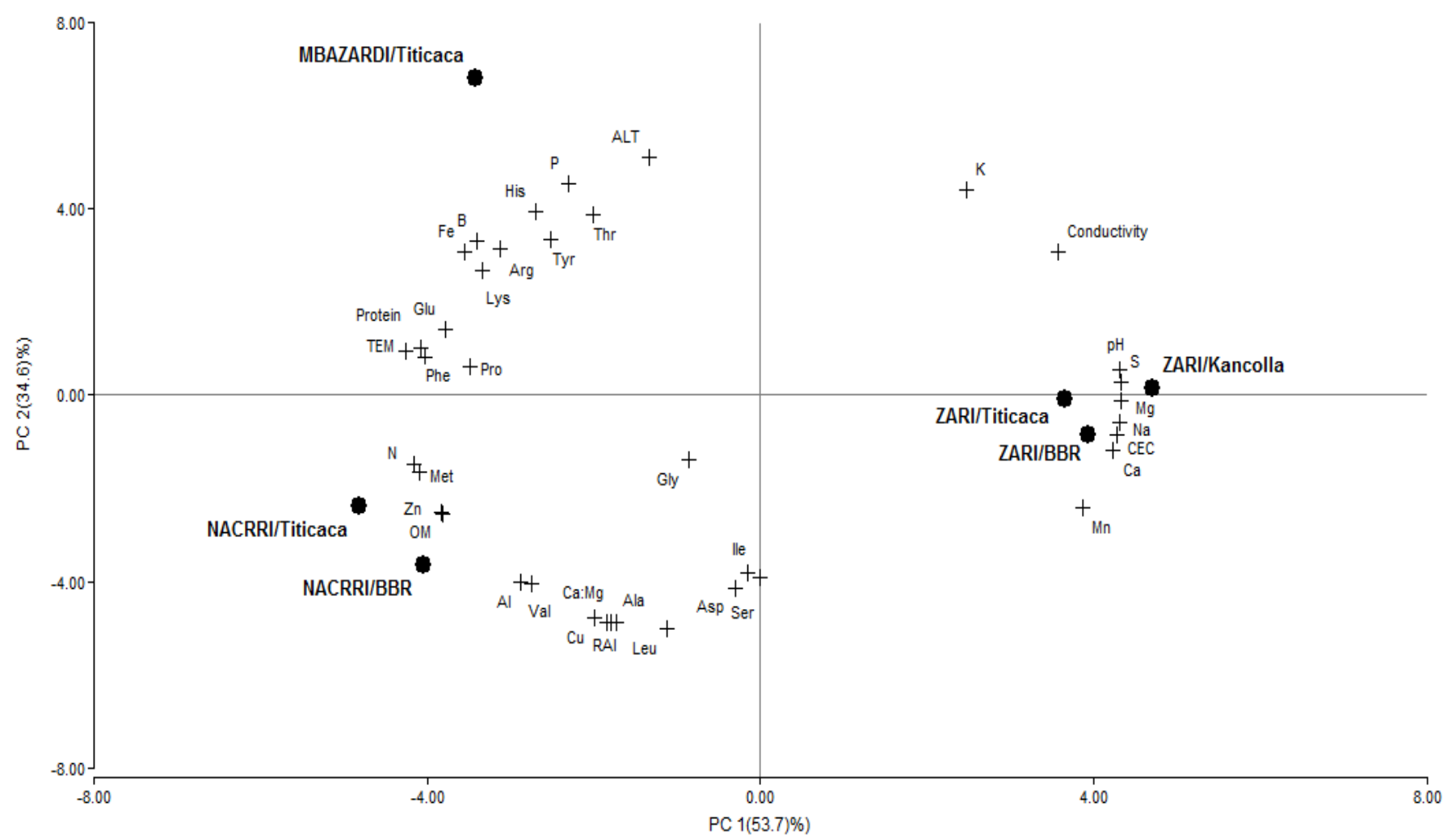

Figure 2: The principal component analysis biplot of quinoa seeds' protein content, amino acid profiles, and agroecological characteristics [black crosses] of three genotypes grown in Namulonge [NaCRRI] and Mbarara [MBAZARDI] in Uganda and Mount Makulu [ZARI] in Zambia [black circles] TEM=Temperature; RAI=Rainfall; ALT=Altitude

A critical component of the quinoa project in Africa has been the mainstreaming of nutrition into its objectives, to assess the quality of the grain in addition to its agronomic performance. The quinoa nutrient profile results imply that the suitability and adoption of quinoa into the African agricultural systems will be influenced by a variety of biophysical factors. This poses a challenge when scaling out the project because efforts to maximize grain quality will require deliberate targeting of agro-ecologies that can produce superior grain in terms of nutritional content.

Anticipating this, CIAT has designed a user-friendly GIS tool for targeting and assessing the out-scaling potential of interventions in agricultural systems. The tool has three distinct functionalities. Firstly, the suitability mapping module enables spatially-explicit matching of conditions hypothesized to favor the successful implementation of a potential intervention within a spatial database. As such, the tool maps out the geographical areas where this specific strategy is likely to have a positive impact. 


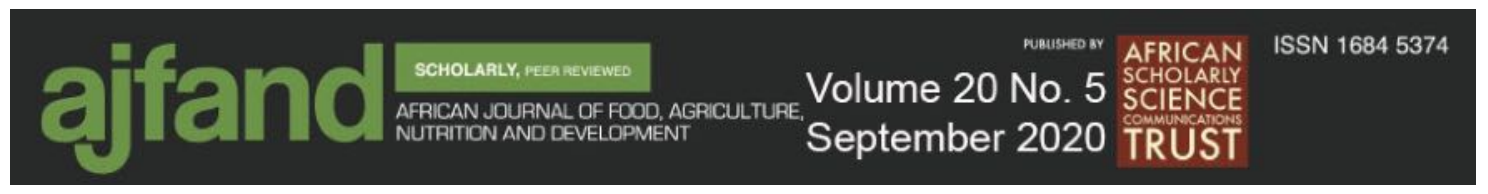

Secondly, the out-scaling module estimates the applicability of successful pilots beyond the local level; the potential for out-scaling is estimated using socioecological characterization and similarity analysis. A visual output in the form of a map indicates where else the intervention is likely to be applicable. Thirdly, the characterization module provides the functionality of further characterizing the outputs from modules one and two, for example, in terms of area covered, total production affected, or the number of animals and people reached. The tool is packaged together with a spatial database covering a variety of thematic areas, including indicators of natural, human, social, financial, and physical capital. This tool will be useful to scale out the production of quinoa in Africa, the next phase of the quinoa project.

\section{CONCLUSION}

Quinoa has been singled out as a food with high nutritional value, impressive biodiversity, and an important role to play in the achievement of food and nutrition security worldwide. FAO commemorated 2013 as the 'The International Year of the Quinoa,' as a superfood of the Andes due to its high nutritional value. The potential for quinoa to diversify agricultural systems and diets in Africa has been demonstrated in the present study. In terms of protein content, the Kancolla variety showed the highest potential, given that its content in seeds grown in Kenya, Uganda, and Zambia was higher than in those grown in Peru. Though the content of the other varieties grown in other respective countries was lower than those grown in Peru, it was still higher than in cereals commonly grown in Africa. All three varieties, therefore, have the potential for diversification. In the case of amino acids, methionine was one of the nutritionally relevant amino acids that was lower in seeds grown in Africa than those grown in Peru, and was found to be limiting in quinoa.

With regards to environmental influences, the protein content was high in soils with a low $\mathrm{pH}$, a high nitrogen content, and in high altitude areas. The present study, therefore, shows that quinoa could potentially be introduced in Africa to diversify diets, if the crop is grown in high altitude regions. Further studies are needed to analyze the impact of the farming system and the environment on other nutrients, such as minerals and vitamins, to demonstrate the full nutritional potential of quinoa in Africa.

\section{ACKNOWLEDGEMENTS}

This work was supported by the Food and Agriculture Organization of the United Nations [FAO] through a Technical Cooperation Programme (TCP) project. The authors also thank the International Center for Tropical Agriculture [CIAT] team for their support in the development of the GIS tool. 


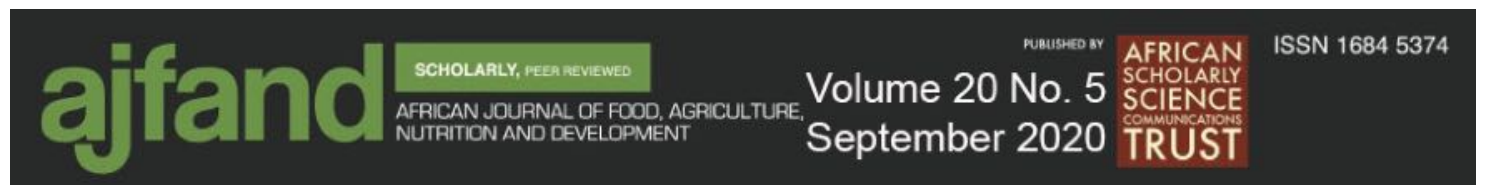

Table 1: Mean [g/100g protein] of non-essential amino acids in Kancolla, Titicaca and BBR varieties grown in Africa and Peru $[n=6]$

\begin{tabular}{|c|c|c|c|c|c|}
\hline \multirow[b]{2}{*}{ Amino acids } & \multicolumn{4}{|c|}{ Country $^{\dagger}$} & \multirow[b]{2}{*}{ Zambia } \\
\hline & Peru* & Ethiopia & Kenya & Uganda & \\
\hline \multicolumn{6}{|l|}{ Kancolla } \\
\hline Aspartic acid & $9.59 \pm 2.21^{\mathrm{a}}$ & $10.5 \pm 3.01^{\mathrm{a}}$ & $10.53 \pm 0.12^{\mathrm{a}}$ & -- & $11.37 \pm 0.11^{\mathrm{a}}$ \\
\hline Serine & $9.31 \pm 2.18^{\mathrm{a}}$ & $8.24 \pm 2.47^{\mathrm{a}}$ & $8.16 \pm 3.43^{\mathrm{a}}$ & -- & $8.16 \pm 5.14^{\mathrm{a}}$ \\
\hline Glutamic acid & $15.17 \pm 4.09^{\mathrm{a}}$ & $15.54 \pm 4.12^{\mathrm{a}}$ & $15.79 \pm 3.30^{\mathrm{a}}$ & -- & $15.42 \pm 4.17^{\mathrm{a}}$ \\
\hline Proline & $4.63 \pm 1.04^{\mathrm{a}}$ & $5.24 \pm 1.22^{\mathrm{a}}$ & $5.07 \pm 2.95^{\mathrm{a}}$ & -- & $4.88 \pm 2.99^{\mathrm{a}}$ \\
\hline Glycine & $8.96 \pm 2.21^{\mathrm{a}}$ & $7.80 \pm 2.14^{\mathrm{a}}$ & $9.01 \pm 3.34^{\mathrm{a}}$ & -- & $9.07 \pm 3.23^{\mathrm{a}}$ \\
\hline Alanine & $5.73 \pm 2.39^{\mathrm{a}}$ & $5.81 \pm 1.10^{\mathrm{a}}$ & $5.66 \pm 1.19^{\mathrm{a}}$ & -- & $5.86 \pm 1.12^{\mathrm{a}}$ \\
\hline Tyrosine & $2.23 \pm 1.21^{\mathrm{a}}$ & $2.87 \pm 1.46^{\mathrm{b}}$ & $2.63 \pm 0.96^{\mathrm{b}}$ & -- & $3.07 \pm 1.44^{\mathrm{b}}$ \\
\hline Arginine & $7.34 \pm 2.23^{\mathrm{a}}$ & $8.93 \pm 2.28^{\mathrm{a}}$ & $7.57 \pm 2.12^{\mathrm{a}}$ & -- & $7.96 \pm 2.96^{\mathrm{a}}$ \\
\hline \multicolumn{6}{|l|}{ Titicaca } \\
\hline Aspartic acid & $11.86 \pm 3.22^{\mathrm{a}}$ & $9.12 \pm 3.71^{\mathrm{a}}$ & $8.77 \pm 3.95^{\mathrm{a}}$ & $9.63 \pm 3.89^{\mathrm{a}}$ & $11.24 \pm 3.63^{\mathrm{a}}$ \\
\hline Serine & $7.99 \pm 2.61^{\mathrm{a}}$ & $6.31 \pm 2.82^{\mathrm{a}}$ & $5.83 \pm 1.36^{\mathrm{a}}$ & $5.68 \pm 1.63^{\mathrm{a}}$ & $7.45 \pm 2.18^{\mathrm{a}}$ \\
\hline Glutamic acid & $16.89 \pm 4.34^{\mathrm{a}}$ & $14.86 \pm 4.73^{\mathrm{a}}$ & $15.20 \pm 5.96^{\mathrm{a}}$ & $16.60 \pm 3.93^{\mathrm{a}}$ & $17.43 \pm 4.96^{\mathrm{a}}$ \\
\hline Proline & $4.89 \pm 1.19^{\mathrm{a}}$ & $4.70 \pm 1.95^{\mathrm{a}}$ & $4.32 \pm 2.36^{\mathrm{a}}$ & $6.27 \pm 1.97^{\mathrm{b}}$ & $4.92 \pm 1.73^{\mathrm{a}}$ \\
\hline Glycine & $6.51 \pm 2.99^{\mathrm{a}}$ & $6.71 \pm 3.33^{\mathrm{a}}$ & $7.15 \pm 2.89^{\mathrm{a}}$ & $8.14 \pm 2.63^{\mathrm{a}}$ & $8.57 \pm 2.32^{\mathrm{a}}$ \\
\hline Alanine & $5.92 \pm 2.78^{\mathrm{a}}$ & $4.76 \pm 2.43^{\mathrm{a}}$ & $4.44 \pm 1.66^{\mathrm{a}}$ & $4.84 \pm 1.98^{\mathrm{a}}$ & $5.62 \pm 1.78^{\mathrm{a}}$ \\
\hline Tyrosine & $3.10 \pm 1.32^{\mathrm{b}}$ & $2.75 \pm 1.62^{\mathrm{a}}$ & $2.16 \pm 1.52^{\mathrm{a}}$ & $3.10 \pm 1.32^{\mathrm{b}}$ & $3.02 \pm 1.29^{\mathrm{b}}$ \\
\hline Arginine & $8.56 \pm 3.10^{\mathrm{a}}$ & $8.38 \pm 3.22^{\mathrm{a}}$ & $7.81 \pm 1.19^{\mathrm{a}}$ & $11.11 \pm 3.72^{b}$ & $8.92 \pm 2.69^{\mathrm{a}}$ \\
\hline \multicolumn{6}{|l|}{ BBR } \\
\hline Aspartic acid & $12.95 \pm 3.22^{\mathrm{b}}$ & $9.63 \pm 1.22^{\mathrm{a}}$ & $9.30 \pm 1.36^{\mathrm{a}}$ & $8.50 \pm 1.74^{\mathrm{a}}$ & $11.5 \pm 4.65^{\mathrm{a}}$ \\
\hline Serine & $9.87 \pm 2.43^{\mathrm{c}}$ & $7.27 \pm 1.62^{\mathrm{b}}$ & $6.36 \pm 1.23^{\mathrm{b}}$ & $4.93 \pm 1.28^{\mathrm{a}}$ & $7.84 \pm 3.23^{b}$ \\
\hline Glutamic acid & $17.94 \pm 5.16^{\mathrm{c}}$ & $15.22 \pm 5.65^{\mathrm{a}}$ & $15.46 \pm 3.22^{\mathrm{a}}$ & $15.34 \pm 4.23^{\mathrm{a}}$ & $16.91 \pm 5.63^{\mathrm{a},}$ \\
\hline Proline & $4.63 \pm 1.07^{\mathrm{a}}$ & $4.97 \pm 1.33^{\mathrm{a}}$ & $4.69 \pm 1.17^{\mathrm{a}}$ & $4.13 \pm 1.98^{\mathrm{a}}$ & $4.95 \pm 1.98^{\mathrm{a}}$ \\
\hline Alanine & $6.88 \pm 2.11^{\mathrm{a}}$ & $5.22 \pm 1.27^{\mathrm{a}}$ & $5.29 \pm 1.63^{\mathrm{a}}$ & $4.50 \pm 2.36^{\mathrm{a}}$ & $6.32 \pm 2.78^{\mathrm{a}}$ \\
\hline Tyrosine & $1.53 \pm 0.23^{\mathrm{a}}$ & $2.73 \pm 1.17^{b}$ & $2.14 \pm 1.91^{b}$ & $3.14 \pm 1.69^{\mathrm{c}}$ & $2.82 \pm 0.32^{\mathrm{b}}$ \\
\hline Arginine & $8.90 \pm 2.08^{b}$ & $8.82 \pm 1.96^{\mathrm{b}}$ & $7.76 \pm 1.24^{\mathrm{a}}$ & $8.32 \pm 1.78^{b}$ & $8.68 \pm 1.91^{\mathrm{b}}$ \\
\hline
\end{tabular}

Values of mean \pm standard deviation with different superscript letters within a row statistically differed with country $[P<0.05]$

*Country where reference seeds, which are the original quinoa seeds were grown 


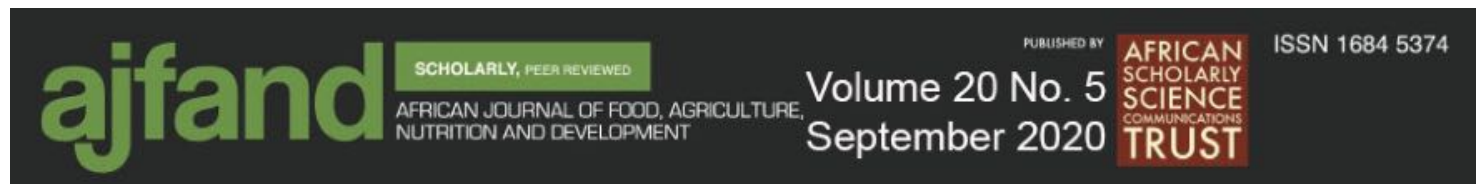

Table 2: Mean [g/100g protein] of essential amino acids in Kancolla, Titicaca and BBR variety grown in Africa and Peru [n=6]

\begin{tabular}{|c|c|c|c|c|c|c|}
\hline \multirow[b]{2}{*}{ Amino acids } & \multicolumn{6}{|c|}{ Country } \\
\hline & $\mathrm{HR}^{¥}$ & Peru* & Ethiopia & Kenya & Uganda & Zambia \\
\hline \multicolumn{7}{|l|}{ Kancolla } \\
\hline Threonine & 2.3 & $5.95 \pm 2.67^{\mathrm{a}}$ & $5.31 \pm 1.22^{\mathrm{a}}$ & $5.39 \pm 1.65^{\mathrm{a}}$ & -- & $5.65 \pm 1.14^{\mathrm{a}}$ \\
\hline Valine & 3.9 & $4.23 \pm 2.44^{\mathrm{a}}$ & $6.24 \pm 2.13^{\mathrm{a}}$ & $4.87 \pm 2.33^{\mathrm{a}}$ & -- & $5.79 \pm 2.36^{\mathrm{a}}$ \\
\hline Methionine & 1.6 & $1.36 \pm 2.93^{\mathrm{b}}$ & $1.25 \pm 1.28^{\mathrm{b}}$ & $1.51 \pm 0.15^{\mathrm{b}}$ & -- & $0.91 \pm 0.78^{\mathrm{a}}$ \\
\hline Isoleucine & 3.0 & $4.72 \pm 2.31^{\mathrm{a}}$ & $5.68 \pm 1.81^{\mathrm{a}}$ & $4.93 \pm 1.65^{\mathrm{a}}$ & -- & $5.44 \pm 1.32^{\mathrm{a}}$ \\
\hline Leucine & 5.9 & $7.22 \pm 2.04^{\mathrm{a}}$ & $7.87 \pm 2.33^{\mathrm{b}}$ & $7.63 \pm 2.54^{\mathrm{a}, \mathrm{b}}$ & -- & $8.23 \pm 2.47^{b}$ \\
\hline Phenylalanine & 3.8 & $2.42 \pm 1.01^{\mathrm{a}}$ & $3.81 \pm 1.51^{\mathrm{c}}$ & $3.22 \pm 0.87^{\mathrm{b}}$ & -- & $2.93 \pm 0.91^{\mathrm{a}, \mathrm{b}}$ \\
\hline Lysine & 4.5 & $6.82 \pm 1.02^{\mathrm{a}}$ & $6.49 \pm 1.31^{\mathrm{a}}$ & $6.51 \pm 1.81^{\mathrm{a}}$ & -- & $6.70 \pm 2.65^{\mathrm{a}}$ \\
\hline Histidine & 1.5 & $3.29 \pm 1.11^{\mathrm{a}}$ & $3.43 \pm 0.67^{\mathrm{a}}$ & $3.62 \pm 0.47^{\mathrm{a}}$ & -- & $4.05 \pm 1.95^{\mathrm{a}}$ \\
\hline \multicolumn{7}{|l|}{ Titicaca } \\
\hline Threonine & 2.3 & $3.62 \pm 1.28^{\mathrm{a}}$ & $4.07 \pm 1.18^{\mathrm{a}}$ & $4.44 \pm 1.14^{\mathrm{a}, \mathrm{b}}$ & $5.88 \pm 1.18^{\mathrm{b}}$ & $5.48 \pm 1.97^{\mathrm{b}}$ \\
\hline Valine & 3.9 & $6.78 \pm 1.21^{\mathrm{d}}$ & $5.16 \pm 2.62^{\mathrm{c}}$ & $3.78 \pm 1.47^{\mathrm{a}}$ & $4.84 \pm 1.68^{\mathrm{b}}$ & $5.62 \pm 1.61^{\mathrm{c}}$ \\
\hline Methionine & 1.6 & $1.96 \pm 0.22^{\mathrm{c}}$ & $1.32 \pm 1.69^{\mathrm{a}}$ & $1.86 \pm 0.19^{\mathrm{c}}$ & $1.29 \pm 0.53^{\mathrm{a}}$ & $1.41 \pm 0.68^{\mathrm{b}}$ \\
\hline Isoleucine & 3.0 & $4.26 \pm 1.12^{\mathrm{a}}$ & $4.13 \pm 1.38^{\mathrm{a}}$ & $4.20 \pm 1.98^{\mathrm{a}}$ & $4.46 \pm 1.97^{\mathrm{a}}$ & $5.41 \pm 1.39^{\mathrm{a}}$ \\
\hline Leucine & 5.9 & $7.25 \pm 3.25^{\mathrm{a}}$ & $6.71 \pm 2.12^{\mathrm{a}}$ & $6.43 \pm 2.17^{\mathrm{a}}$ & $6.98 \pm 2.37^{\mathrm{a}}$ & $8.29 \pm 4.96^{\mathrm{a}}$ \\
\hline Phenylalanine & 3.8 & $4.96 \pm 1.26^{\mathrm{c}}$ & $3.73 \pm 0.30^{\mathrm{b}}$ & $2.88 \pm 0.24^{\mathrm{a}}$ & $3.68 \pm 1.64^{\mathrm{b}}$ & $3.09 \pm 1.34^{\mathrm{a}, \mathrm{b}}$ \\
\hline Lysine & 4.5 & $5.68 \pm 2.11^{\mathrm{a}}$ & $5.74 \pm 2.47^{\mathrm{a}}$ & $6.19 \pm 2.97^{\mathrm{a}, \mathrm{b}}$ & $9.11 \pm 2.39^{c}$ & $7.10 \pm 2.16^{\mathrm{b}}$ \\
\hline Histidine & 1.5 & $3.56 \pm 1.08^{\mathrm{a}}$ & $3.16 \pm 1.93^{\mathrm{a}}$ & $3.24 \pm 0.90^{\mathrm{a}}$ & $6.78 \pm 1.71^{\mathrm{b}}$ & $3.94 \pm 1.56^{\mathrm{a}}$ \\
\hline \multicolumn{7}{|l|}{ BBR } \\
\hline Threonine & 2.3 & $6.58 \pm 0.12^{\mathrm{c}}$ & $4.72 \pm 1.18^{\mathrm{a}, \mathrm{b}}$ & $4.69 \pm 1.62^{\mathrm{a}, \mathrm{b}}$ & $4.00 \pm 1.68^{\mathrm{a}}$ & $5.86 \pm 1.52^{\mathrm{b}}$ \\
\hline Valine & 3.9 & $4.73 \pm 0.08^{\mathrm{a}}$ & $5.59 \pm 2.62^{\mathrm{b}}$ & $4.48 \pm 1.78^{\mathrm{a}}$ & $4.93 \pm 1.22^{\mathrm{a}, \mathrm{b}}$ & $5.79 \pm 1.73^{b}$ \\
\hline Methionine & 1.6 & $2.31 \pm 0.02^{\mathrm{c}}$ & $1.24 \pm 0.18^{\mathrm{b}}$ & $1.94 \pm 0.62^{\mathrm{b}, \mathrm{c}}$ & $1.29 \pm 0.91^{\mathrm{b}}$ & $0.91 \pm 0.62^{\mathrm{a}}$ \\
\hline Isoleucine & 3.0 & $5.88 \pm 0.05^{\mathrm{a}, \mathrm{b}}$ & $4.41 \pm 1.84^{\mathrm{a}}$ & $4.62 \pm 1.22^{\mathrm{a}}$ & $4.19 \pm 1.63^{\mathrm{a}}$ & $5.48 \pm 1.25^{\mathrm{a} . \mathrm{b}}$ \\
\hline Leucine & 5.9 & $8.93 \pm 0.09^{b}$ & $7.33 \pm 2.72^{\mathrm{a}}$ & $7.43 \pm 2.29^{\mathrm{a}}$ & $6.41 \pm 1.76^{\mathrm{a}}$ & $8.68 \pm 3.82^{\mathrm{b}}$ \\
\hline Phenylalanine & 3.8 & $3.53 \pm 1.03^{\mathrm{c}}$ & $3.73 \pm 1.09^{\mathrm{d}}$ & $3.01 \pm 1.19^{\mathrm{b}}$ & $3.08 \pm 0.48^{\mathrm{b}, \mathrm{c}}$ & $2.82 \pm 1.81^{\mathrm{a}}$ \\
\hline Lysine & 4.5 & $6.87 \pm 0.04^{\mathrm{b}}$ & $6.65 \pm 2.75^{\mathrm{b}}$ & $7.16 \pm 2.22^{\mathrm{b}, \mathrm{c}}$ & $5.79 \pm 1.93^{\mathrm{a}}$ & $7.46 \pm 1.77^{\mathrm{c}}$ \\
\hline Histidine & 1.5 & $3.61 \pm 0.07^{\mathrm{a}}$ & $3.54 \pm 1.26^{\mathrm{a}}$ & $3.48 \pm 1.27^{\mathrm{a}}$ & $3.57 \pm 1.74^{\mathrm{a}}$ & $4.11 \pm 1.93^{\mathrm{a}}$ \\
\hline
\end{tabular}

Values of mean \pm standard deviation with different superscript letters within a row statistically differed with country $[P<0.05]$

${ }^{\sharp} \mathrm{HR}$ : Human requirements for essential amino acids as per the $\mathrm{WHO} / \mathrm{FAO} / \mathrm{UNU}$ guidelines

*Country where reference seeds, which are the original quinoa seeds, were grown 


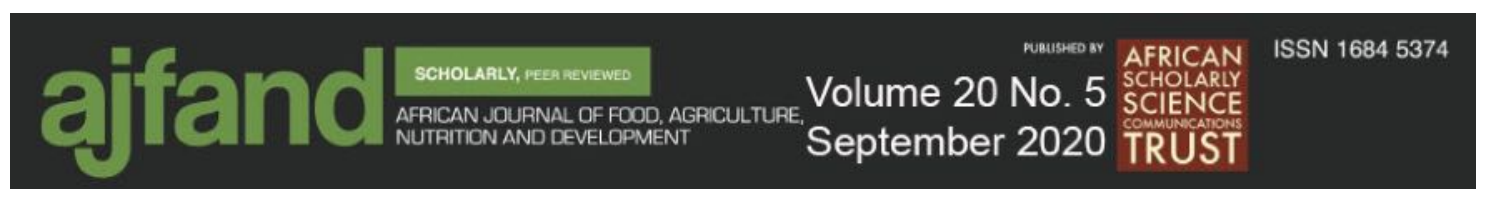

Table 3: The amino acid [chemical] score of quinoa grown in Peru, Ethiopia, Kenya, Uganda, and Zambia, determined using WHO/FAO/UNU guidelines $^{\mathbf{a}} \cdot[\mathrm{n}=6]$

\begin{tabular}{|c|c|c|c|c|c|}
\hline \multirow[b]{2}{*}{ Amino acids } & \multicolumn{4}{|c|}{ Country $^{\dagger}$} & \multirow[b]{2}{*}{ Zambia } \\
\hline & Peru* & Ethiopia & Kenya & Uganda & \\
\hline \multicolumn{6}{|l|}{ Kancolla } \\
\hline Threonine & 2.59 & 2.31 & 2.34 & -- & 2.46 \\
\hline Valine & 1.08 & 1.60 & 1.25 & -- & 1.48 \\
\hline Methionine & $0.85^{\S}$ & $0.78^{¥}$ & $0.76^{¥}$ & -- & $0.57^{¥}$ \\
\hline Isoleucine & 1.57 & 1.89 & 1.64 & -- & 1.81 \\
\hline Leucine & 1.22 & 1.33 & 1.29 & -- & 1.39 \\
\hline Phenylalanine & $0.64^{¥}$ & $1.00^{\S}$ & $0.85^{\S}$ & -- & $0.77^{\S}$ \\
\hline Lysine & 1.52 & 1.44 & 1.45 & -- & 1.49 \\
\hline Histidine & 2.19 & 2.29 & 2.41 & -- & 2.70 \\
\hline \multicolumn{6}{|l|}{ Titicaca } \\
\hline Threonine & 1.57 & 1.77 & 1.93 & 2.56 & 2.38 \\
\hline Valine & 1.74 & 1.32 & $0.97^{\S}$ & 1.24 & 1.44 \\
\hline Methionine & $1.23^{¥}$ & $0.83^{¥}$ & 1.16 & $0.81^{¥}$ & $0.88^{\S}$ \\
\hline Isoleucine & 1.42 & 1.38 & 1.40 & 1.49 & 1.80 \\
\hline Leucine & $1.25^{\S}$ & 1.14 & 1.09 & 1.18 & 1.41 \\
\hline Phenylalanine & 1.31 & $0.98^{\S}$ & $0.76^{¥}$ & $0.97^{\S}$ & $0.81^{¥}$ \\
\hline Lysine & 1.26 & 1.28 & 1.38 & 2.02 & 1.58 \\
\hline Histidine & 2.37 & 2.11 & 2.16 & 4.52 & 2.63 \\
\hline \multicolumn{6}{|l|}{ BBR } \\
\hline Threonine & 2.86 & 2.05 & 2.04 & 1.74 & 2.55 \\
\hline Valine & $1.21^{\S}$ & 1.43 & $1.15^{\S}$ & 1.26 & 1.48 \\
\hline Methionine & 1.44 & $0.78^{¥}$ & 1.21 & $0.81^{¥}$ & $0.57^{¥}$ \\
\hline Isoleucine & 1.96 & 1.47 & 1.54 & 1.40 & 1.83 \\
\hline Leucine & 1.51 & 1.24 & 1.26 & 1.09 & 1.47 \\
\hline Phenylalanine & $0.93^{¥}$ & $0.98^{\S}$ & $0.79^{¥}$ & $0.83^{\S}$ & $0.74^{\S}$ \\
\hline Lysine & 1.53 & 1.48 & 1.59 & 1.29 & 1.66 \\
\hline Histidine & 2.41 & 2.36 & 2.32 & 2.38 & 2.74 \\
\hline
\end{tabular}

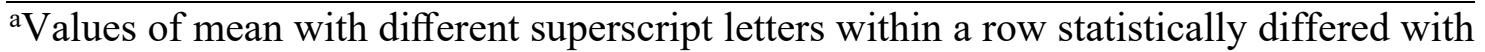
country $[P<0.05]$

*Country where reference seeds, which are the original quinoa seeds, were grown

${ }^{\sharp}$ First limiting amino acid

${ }^{\S}$ Second limiting amino acid 


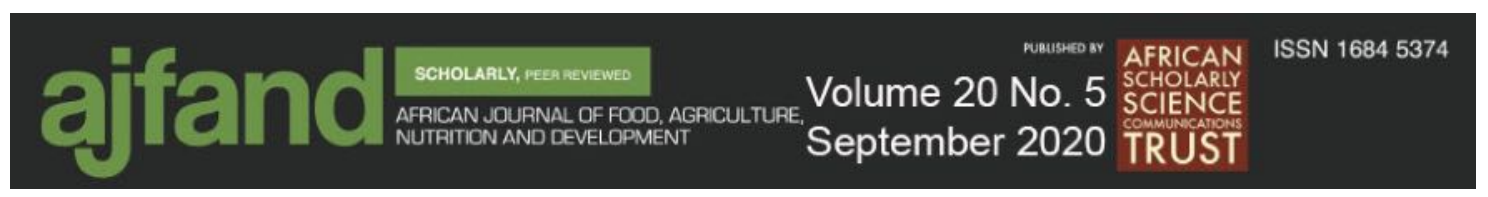

Table 4: Altitude, climatic and soil characteristic of study sites in Uganda [Mbarara and Namulonge] and Zambia [Mount Makulu]

\begin{tabular}{|c|c|c|c|}
\hline & \multicolumn{2}{|c|}{ Uganda } & \multirow{2}{*}{$\frac{\text { Zambia }}{\text { Mount Makult }}$} \\
\hline & Mbarara & Namulonge & \\
\hline Altitude [m] & 1800 & 1180 & 1213 \\
\hline Annual mean rainfall $[\mathrm{mm}]$ & 900 & 1135 & 1000 \\
\hline Annual mean temperature $\left[{ }^{\circ} \mathrm{C}\right]$ & 26.45 & 25.70 & 20.5 \\
\hline \multicolumn{4}{|l|}{ Salinity } \\
\hline $\mathrm{pH}$ at $25^{\circ} \mathrm{C}$ & $5.16 \pm 0.04^{\mathrm{b}}$ & $4.38 \pm 0.05^{\mathrm{a}}$ & $7.41 \pm 0.03^{\mathrm{c}}$ \\
\hline Conductivity at $25^{\circ} \mathrm{C}[\mathrm{mmhos} / \mathrm{cm}]$ & $0.29 \pm 0.04^{\mathrm{b}}$ & $0.09 \pm 0.00^{\mathrm{a}}$ & $0.31 \pm 0.01^{\mathrm{b}}$ \\
\hline \multicolumn{4}{|l|}{ Fertility } \\
\hline Organic matter $[\% \mathrm{wt}]$ & $2.29 \pm 0.27^{\mathrm{b}}$ & $3.40 \pm 0.06^{\mathrm{c}}$ & $1.89 \pm 0.11^{\mathrm{a}}$ \\
\hline Total nitrogen in soil $[\%]$ & $0.14 \pm 0.01^{\mathrm{b}}$ & $0.17 \pm 0.00^{\mathrm{c}}$ & $0.10 \pm 0.00^{\mathrm{a}}$ \\
\hline Phosphorous [mg kg-1] & $64.93 \pm 29.59^{\mathrm{a}}$ & $34.09 \pm 0.62^{\mathrm{a}}$ & $28.99 \pm 0.52^{\mathrm{a}}$ \\
\hline Potassium [mg kg-1] & $454.03 \pm 89.78^{\mathrm{b}}$ & $128.65 \pm 0.18^{\mathrm{a}}$ & $362.90 \pm 0.29^{\mathrm{b}}$ \\
\hline \multicolumn{4}{|l|}{ Micronutrients [mg kg-1] } \\
\hline Calcium & $2548.54 \pm 488.82^{\mathrm{a}}$ & $3168.00 \pm 7.25^{\mathrm{b}}$ & $5912.21 \pm 4.15^{\mathrm{c}}$ \\
\hline Magnesium & $231.74 \pm 22.39^{\mathrm{a}}$ & $209.48 \pm 0.55^{\mathrm{a}}$ & $466.85 \pm 1.45^{\mathrm{b}}$ \\
\hline Sodium & $354.68 \pm 5.86^{\mathrm{a}}$ & $358.34 \pm 1.87^{\mathrm{a}}$ & $439.18 \pm 7.09^{\mathrm{b}}$ \\
\hline Aluminium & $730.47 \pm 122.70^{\mathrm{a}}$ & $832.74 \pm 1.65^{\mathrm{a}}$ & $747.16 \pm 2.19^{\mathrm{a}}$ \\
\hline Sulphur & $16.97 \pm 4.51^{\mathrm{a}}$ & $12.58 \pm 0.13^{\mathrm{a}}$ & $35.52 \pm 0.29^{\mathrm{b}}$ \\
\hline Iron & $151.15 \pm 35.33^{b}$ & $119.70 \pm 0.08^{\mathrm{b}}$ & $94.30 \pm 0.38^{\mathrm{a}}$ \\
\hline Manganese & $184.80 \pm 46.05^{\mathrm{a}}$ & $204.93 \pm 0.04^{\mathrm{a}}$ & $231.42 \pm 0.19^{\mathrm{a}}$ \\
\hline Copper & $2.35 \pm 0.53^{\mathrm{a}}$ & $4.77 \pm 0.02^{\mathrm{c}}$ & $3.30 \pm 0.04^{\mathrm{b}}$ \\
\hline Boron & $1.56 \pm 0.12^{\mathrm{b}}$ & $1.31 \pm 0.04^{\mathrm{a}}$ & $1.14 \pm 0.09^{\mathrm{a}}$ \\
\hline Zinc & $2.97 \pm 0.74^{\mathrm{a}}$ & $4.82 \pm 0.12^{\mathrm{b}}$ & $2.27 \pm 0.16^{\mathrm{a}}$ \\
\hline Ca:Mg Ratio & $10.91 \pm 1.06^{\mathrm{a}}$ & $15.12 \pm 0.01^{\mathrm{c}}$ & $12.66 \pm 0.05^{\mathrm{b}}$ \\
\hline $\begin{array}{l}\text { Cation Exchange Capacity } \\
{[\mathrm{Meq} / 100 \mathrm{~g}]}\end{array}$ & $17.38 \pm 2.89^{\mathrm{a}}$ & $19.47 \pm 0.03^{\mathrm{a}}$ & $36.29 \pm 0.03^{b}$ \\
\hline
\end{tabular}




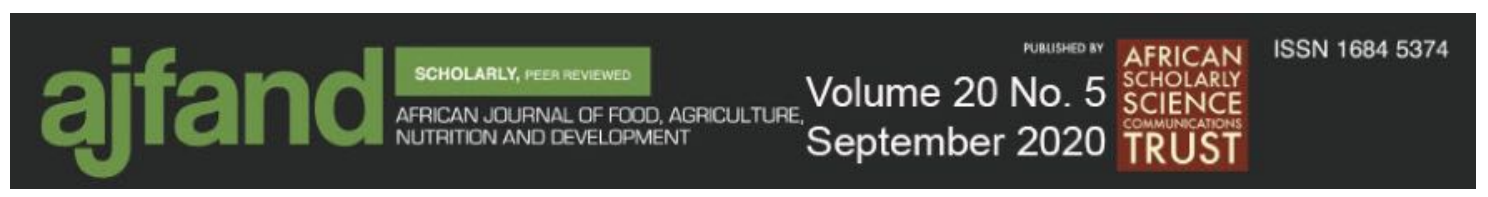

Table 5: The protein content [\%] and amino acid profile [g/100g protein] of quinoa seeds grown in different research sites in Uganda [Mbarara and Namulonge] and Zambia [Mount Makulu]

\begin{tabular}{|c|c|c|c|c|c|c|}
\hline & \multicolumn{3}{|c|}{ Titicaca } & \multicolumn{2}{|c|}{$\mathrm{BBR}$} & \multirow{2}{*}{$\begin{array}{l}\text { Kancolla } \\
\text { Mount } \\
\text { Makulu }\end{array}$} \\
\hline & Mbarara & Namulonge & $\begin{array}{l}\text { Mount } \\
\text { Makulu }\end{array}$ & Namulonge & $\begin{array}{l}\text { Mount } \\
\text { Makulu }\end{array}$ & \\
\hline Protein & $17.22 \pm 0.32$ & $16.17 \pm 0.23$ & $14.23 \pm 0.25$ & $16.93 \pm 0.15$ & $14.33 \pm 0.21$ & $13.13 \pm 0.25$ \\
\hline \multicolumn{7}{|c|}{ Non-essential amino acids } \\
\hline Aspartic acid & $8.65 \pm 2.23$ & $9.71 \pm 3.32$ & $11.24 \pm 3.89$ & $9.98 \pm 2.75$ & $11.44 \pm 3.63$ & $11.50 \pm 2.05$ \\
\hline Serine & $4.99 \pm 1.21$ & $7.98 \pm 2.16$ & $7.45 \pm 2.23$ & $6.08 \pm 2.47$ & $8.16 \pm 2.78$ & $7.84 \pm 2.11$ \\
\hline Glutamic acid & $15.68 \pm 5.61$ & $16.08 \pm 4.97$ & $17.43 \pm 5.87$ & $15.30 \pm 5.65$ & $15.42 \pm 5.98$ & $16.91 \pm 4.65$ \\
\hline Proline & $5.52 \pm 2.95$ & $7.05 \pm 2.20$ & $4.92 \pm 2.19$ & $4.49 \pm 1.42$ & $4.88 \pm 2.48$ & $4.95 \pm 1.02$ \\
\hline Glycine & $7.26 \pm 2.67$ & $7.67 \pm 2.14$ & $8.57 \pm 3.17$ & $7.56 \pm 2.64$ & $9.07 \pm 3.78$ & $9.14 \pm 3.02$ \\
\hline Alanine & $4.30 \pm 1.63$ & $5.69 \pm 2.98$ & $5.62 \pm 2.98$ & $5.61 \pm 2.12$ & $5.86 \pm 2.67$ & $6.32 \pm 2.17$ \\
\hline Tyrosine & $3.14 \pm 1.02$ & $2.66 \pm 1.04$ & $3.02 \pm 1.05$ & $2.72 \pm 1.13$ & $3.07 \pm 2.01$ & $2.82 \pm 1.63$ \\
\hline Arginine & $10.05 \pm 3.38$ & $9.83 \pm 2.26$ & $8.92 \pm 3.01$ & $7.21 \pm 3.57$ & $7.96 \pm 2.36$ & $8.68 \pm 3.57$ \\
\hline \multicolumn{7}{|c|}{ Essential amino acids } \\
\hline Threonine & $5.52 \pm 2.36$ & $4.76 \pm 1.13$ & $5.48 \pm 2.97$ & $5.02 \pm 2.47$ & $5.65 \pm 2.63$ & $5.86 \pm 2.29$ \\
\hline Valine & $4.47 \pm 2.61$ & $5.69 \pm 1.07$ & $5.62 \pm 2.08$ & $5.43 \pm 1.11$ & $5.79 \pm 1.07$ & $5.79 \pm 2.65$ \\
\hline Methionine & $1.16 \pm 0.89$ & $1.73 \pm 0.32$ & $1.12 \pm 0.22$ & $1.59 \pm 0.31$ & $0.91 \pm 0.09$ & $0.91 \pm 0.16$ \\
\hline Isoleucine & $4.07 \pm 1.69$ & $4.51 \pm 2.26$ & $5.41 \pm 2.02$ & $4.90 \pm 2.11$ & $5.44 \pm 2.06$ & $5.48 \pm 3.97$ \\
\hline Leucine & $6.21 \pm 2.36$ & $7.48 \pm 2.03$ & $8.29 \pm 3.07$ & $7.62 \pm 2.02$ & $8.23 \pm 3.08$ & $8.68 \pm 3.57$ \\
\hline Phenylamine & $3.37 \pm 2.68$ & $3.83 \pm 1.63$ & $3.09 \pm 1.97$ & $3.01 \pm 0.93$ & $2.93 \pm 0.63$ & $2.82 \pm 0.68$ \\
\hline Lysine & $7.67 \pm 2.63$ & $7.79 \pm 2.48$ & $7.10 \pm 2.10$ & $6.02 \pm 2.36$ & $6.00 \pm 2.12$ & $7.46 \pm 2.23$ \\
\hline Histidine & $6.39 \pm 1.50$ & $5.19 \pm 2.18$ & $3.94 \pm 1.63$ & $3.31 \pm 1.06$ & $4.05 \pm 1.11$ & $4.11 \pm 1.13$ \\
\hline
\end{tabular}




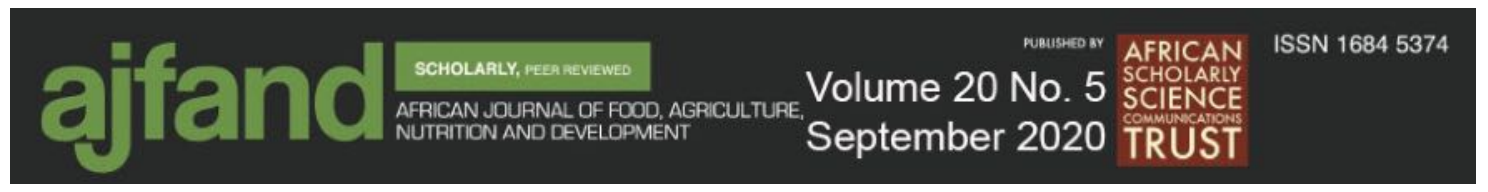

\section{REFERENCES}

1. Semba R D The rise and fall of protein malnutrition in global health. Annals of Nutrition and Metabolism, 2016;69(2): 79-88. http://doi.org/10.1159/000449175

2. De Onis M, Monteiro C, Akré $\mathbf{J}$ and $\mathbf{G}$ Clugston The worldwide magnitude of protein-energy malnutrition: an overview from the WHO Global Database on Child Growth. Bulletin of the World Health Organization, 1993; 71: 703-712.

3. Kamel T B, Deraz T E, Elkabarity R H and RK Ahmed Protein energy malnutrition associates with different types of hearing impairments in toddlers: Anemia increases cochlear dysfunction. International Journal of Pediatric Otorhinolaryngology, 2016; 85: 27-31. http://doi.org/10.1016/j.ijporl.2016.03.018

4. Pelletier D L, Frongillo E A, Habicht $\mathbf{J}$ P and JP Habicht Epidemiologic evidence for a potentiating effect of malnutrition on child mortality. American Journal of Public Health, 1993; 83(8): 1130-3.

5. Thompson $\mathbf{B}$ and $\mathbf{J}$ Meerman Narrowing the Nutrition Gap: Investing In Agriculture to Improve Dietary Diversity. 2013; Rome, Italy.

6. Pingali $\mathbf{P}$ Agricultural policy and nutrition outcomes - getting beyond the preoccupation with staple grains. Food Security, 2015; 7(3): 583-591. http://doi.org/10.1007/s12571-015-0461-X

7. Johnston $\mathbf{J} \mathbf{L}$, Fanzo $\mathbf{J} \mathbf{C}$ and $\mathbf{B}$ Bogil Understanding sustainable diets: a descriptive analysis of the determinants and processes that influence diets and their impact on health, food security, and environmental sustainability. Adv. Nutr, 2014; 5(4): 418-429. http://doi.org/10.3945/an.113.005553.418

8. Ruiz K B, Biondi S, Oses R, Acuña-Rodríguez I S, Antognoni F, MartinezMosqueira E A and MA Molina-Montenegro Quinoa biodiversity and sustainability for food security under climate change. A review. Agronomy for Sustainable Development, 2014; 34: 349-359. http://doi.org/10.1007/s13593-013$\underline{0195-0}$

9. FAO. Prospects for quinoa adaptation and utilization in Eastern and Southern Africa: Technological, institutional and policy considerations, by Maliro, M.F.A., Abang, M., Mukankusi, C., Lung'aho, M., Fenta, B., Wanderi, S., Kapa, R., Okiro, O.A., Koma, E., Mwaba, C., Isse, M.M. \& Bazile, D. Harare, Food and Agriculture Organization of the United Nations (in press) 2020.

10. Stikic R, Glamoclija D, Demin M, Vucelic-Radovic B, Jovanovic Z, Milojkovic-Opsenica, D and M Milovanovic Agronomical and nutritional evaluation of quinoa seeds (Chenopodium quinoa Willd.) as an ingredient in bread formulations. Journal of Cereal Science, 2012; 55(2): 132-138.

http://doi.org/10.1016/j.jcs.2011.10.010 


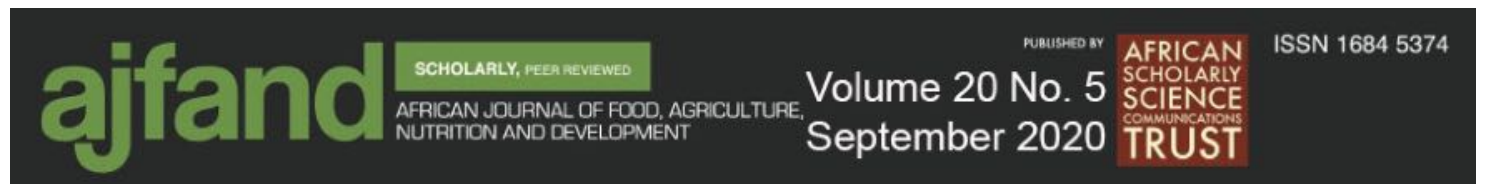

11. Jacobsen SE The Worldwide Potential for Quinoa ( Chenopodium quinoa Willd.). Food Reviews International, 2003; 19(1-2): 167-177. http://doi.org/10.1081/FRI120018883

12. Mujica A, Jacobsen $\mathbf{S}$, Izquierdo $\mathbf{J}$ and $\mathbf{J}$ Marathee Resultados de la Prueba Americana y Europea... 2001 - Google Scholar.

13. Gonzalez J A, Konishi Y, Bruno M, Valoy M and FE Prado Interrelationships among seed yield, total protein and amino acid composition of ten quinoa (Chenopodium quinoa) cultivars from two different agroecological regions. Journal of the Science of Food and Agriculture, 2012; 92(6): 1222-1229. http://doi.org/10.1002/jsfa.4686

14. Miranda M, Vega-Gálvez A, López J, Parada G, Sanders M, Aranda M and K Di Scala Impact of air-drying temperature on nutritional properties, total phenolic content and antioxidant capacity of quinoa seeds (Chenopodium quinoa Willd.). Industrial Crops and Products, 2010; 32(3): 258-263.

http://doi.org/10.1016/j.indcrop.2010.04.019

15. Brend $\mathbf{Y}$, Galili L, Badani H, Hovav $\mathbf{R}$ and $\mathbf{S}$ Galili Total phenolic content and antioxidant activity of red and yellow quinoa seeds as affected by baking and cooking conditions. Food and Nutrition Sciences, 2012; 3(8): 1150-1155. http://doi.org/10.4236/fns.2012.38151

16. Carciochi R A, Manrique G D and K Dimitrov Optimization of antioxidant phenolic compounds extraction from quinoa (Chenopodium quinoa) seeds. Journal of Food Science and Technology, 2015; 52(7): 4396-4404. http://doi.org/10.1007/s13197-014-1514-4

17. Letelier M E, Rodríguez-Rojas $\mathbf{C}$, Sánchez-Jofré $\mathbf{S}$ and $\mathbf{P}$ Aracena-Parks Surfactant and antioxidant properties of an extract from Chenopodium quinoa Willd seed coats. Journal of Cereal Science, 2011; 53(2): 239-243. http://doi.org/10.1016/j.jcs.2010.12.006

18. Lutz M, Martínez A and EA Martínez Daidzein and Genistein contents in seeds of quinoa (Chenopodium quinoa Willd.) from local ecotypes grown in arid Chile. Industrial Crops and Products, 2013; 49: 117-121.

http://doi.org/10.1016/j.indcrop.2013.04.023

19. Repo-Carrasco-Valencia R AM and LA Serna Quinoa (Chenopodium quinoa, Willd.) as a source of dietary fiber and other functional components. Ciência E Tecnologia de Alimentos, 2011; 31(1): 225-230. http://doi.org/10.1590/S0101$\underline{20612011000100035}$ 


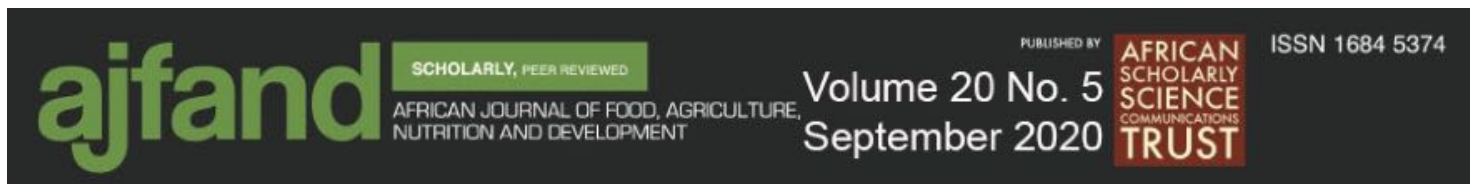

20. Tang Y, Li X, Chen P X, Zhang B, Hernandez M, Zhang $H$ and R Tsao Characterisation of fatty acid, carotenoid, tocopherol/tocotrienol compositions and antioxidant activities in seeds of three Chenopodium quinoa Willd. genotypes. Food Chemistry, 2015; 174(5: 502-508.

http://doi.org/10.1016/j.foodchem.2014.11.040

21. Palombini S V, Claus T, Maruyama S A, Gohara A K, Souza A H P, de Souza $\mathbf{N} \mathbf{E}$ and $M$ Matsushita Evaluation of nutritional compounds in new amaranth and quinoa cultivars. Food Science and Technology, 2013; 33(2): 339-344. http://doi.org/10.1590/S0101-20612013005000051

22. Alvarez-Jubete L, Wijngaard H, Arendt, E K and E Gallagher Polyphenol composition and in vitro antioxidant activity of amaranth, quinoa buckwheat and wheat as affected by sprouting and baking. Food Chemistry, 2010; 119(2): 770778. http://doi.org/10.1016/j.foodchem.2009.07.032

23. Vollmannová A, Margitanová E, Tóth T, Timoracká M, Urminská D, Bojňanská $\mathbf{T}$ and I Čičová Cultivar influence on total polyphenol and rutin contents and total antioxidant capacity in buckwheat, amaranth, and quinoa seeds. Czech Journal of Food Sciences, 2013; 31(6): 589-595.

24. Nascimento A C, Mota C, Coelho I, Gueifão S, Santos M, Matos AS and I Castanheira Characterisation of nutrient profile of quinoa (Chenopodium quinoa), amaranth (Amaranthus caudatus), and purple corn (Zea mays L.) consumed in the North of Argentina: Proximates, minerals and trace elements. Food Chemistry, 2014; 148 (2): 420-426. http://doi.org/10.1016/j.foodchem.2013.09.155

25. Ruiz-Carrasco K, Antognoni F, Coulibaly A K, Lizardi S, Covarrubias A, Martínez E A and A Zurita-Silva Variation in salinity tolerance of four lowland genotypes of quinoa (Chenopodium quinoa Willd.) as assessed by growth, physiological traits, and sodium transporter gene expression. Plant Physiology and Biochemistry, 2011; 49(11): 1333-1341.

http://doi.org/10.1016/j.plaphy.2011.08.005

26. Coulibaly A K, Sangare A, Konate M, Traore S, Ruiz K B, Martínez E A and P Leon Assessment and adaptation of quinoa (Chenopodium quinoa Willd) to the agroclimatic conditions in Mali, West Africa: an example of South-North-South cooperation, 2013.

27. DIN. Food products - Determination of the total nitrogen content by combustion according to the Dumas principle and calculation of the crude protein content - Part 1: Oilseeds and animal feeding stuffs (ISO 16634-1:2008); German version EN ISO 16634-1:2008.

28. Dumas A Stickstoffbestimmung nach Dumas. Die Praxis des org.Chemikers (NDetermination according to Dumas), 1962. Schrag:Nürnberg, Germany. 


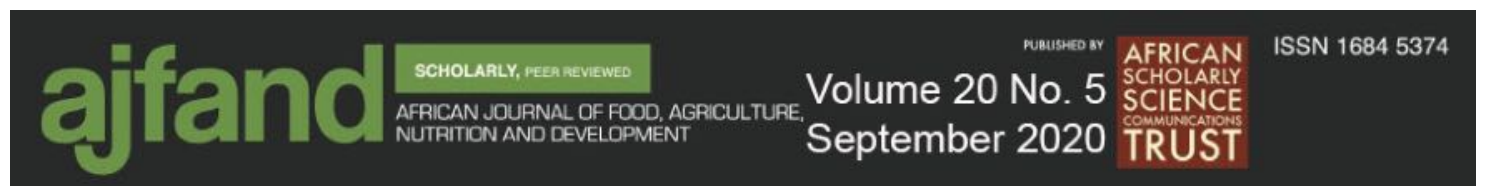

29. Nimbalkar M S, Pai S R, Pawar N V, Oulkar D and GB Dixit Free amino acid profiling in grain Amaranth using LC-MS/MS. Food Chemistry, 2012; 134(4): 2565-2569. http://doi.org/10.1016/j.foodchem.2012.04.057

30. FAO/WHO. Protein quality evaluation in Report of Joint FAO/WHO expert consultation, 1990.

31. WHO/FAO/UNU. Protein and amino acid requirements in human nutrition report of a joint WHO/FAO/UNU expert consultation, 2007. Geneva, Switzerland: World Health Organization.

32. WHO/FAO/UNU. Energy and Protein Requirements: Report of a Joint FAO/WHO/UNU Expert Consultation, 1985.

33. Miranda M, Vega-Gálvez A, Quispe-Fuentes I, Rodríguez M J, Maureira H and EA Martínez Nutritional Aspects of Six Quinoa (Chenopodium quinoa Willd.) Ecotypes from three Geographical Areas of Chile. Chilean Journal of Agricultural Research, 2012; 72(2): 175-181. http://doi.org/10.4067/S0718$\underline{58392012000200002}$

34. Elsohaimy $\mathbf{S}$ A, Refaay $\mathbf{T} \mathbf{M}$ and MAM Zaytoun Physicochemical and functional properties of quinoa protein isolate. Annals of Agricultural Sciences, 2015; 60(2): 297-305. http://doi.org/10.1016/j.aoas.2015.10.007

35. Marmouzi I, El Madani N, Charrouf Z, Cherrah Y and MY El Abbes Faouzi, Proximate analysis, fatty acids and mineral composition of processed Moroccan Chenopodium quinoa Willd. and antioxidant properties according to the polarity. Phytotherapie, 2015; 13(2): 110-117. http://doi.org/10.1007/s10298-015-0931-5

36. Vega-Gálvez A, Miranda M, Vergara J, Uribe E, Puente L and EA Martínez Nutrition facts and functional potential of quinoa (Chenopodium quinoa willd.), an ancient Andean grain: a review. Journal of the Science of Food and Agriculture, 2010; 90 (15): 2541-2547. http://doi.org/10.1002/jsfa.4158

37. Onyango $\mathbf{C}$ Physical properties of dry-milled maize meals and their relationship with the texture of stiff and thin porridge. African Journal of Food Science, 2014; 8(8): 435-443. http://doi.org/10.5897/AJFS2014.1185

38. Wu G, Fanzo J, Miller D D, Pingali P, Post M, Steiner J L and AE ThalackerMercer Production and supply of high-quality food protein for human consumption: Sustainability, challenges, and innovations. Annals of the New York Academy of Sciences, 2014; 1321(1): 1-19. http://doi.org/10.1111/nyas.12500

39. Dini I, Tenore $\mathbf{G} \mathbf{C}$ and A Dini Nutritional and antinutritional composition of Kancolla seeds: An interesting and underexploited andine food plant. Food Chemistry, 2005; 92(1), 125-132. http://doi.org/10.1016/j.foodchem.2004.07.008 


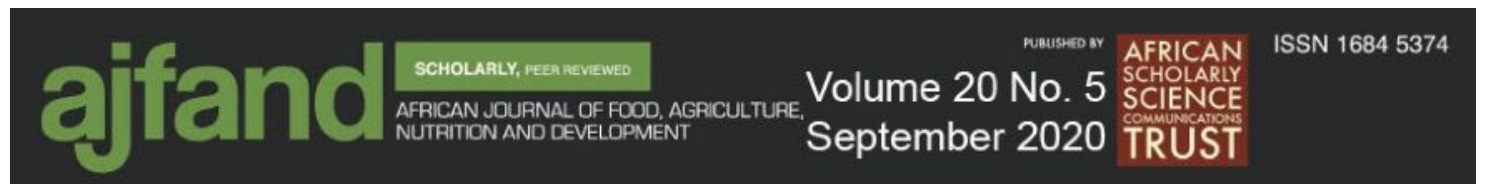

40. Wu G Functional Amino Acids in Growth, Reprodution, and Health. Advances in Nutrition, 2010; 1(4): 31-37. http://doi.org/10.3945/an.110.1008.1

41. Abimorad E G, Ducatti C, Castellani D, Jomori R K, Portella M C and DJ Carneiro The use of stable isotopes to investigate the effects of supplemental lysine and methionine on protein turnover and amino acid utilization in pacu, Piaractus mesopotamicus, juveniles. Aquaculture, 2014; 433: 119-124. http://doi.org/10.1016/j.aquaculture.2014.06.006

42. Galili G and $\mathbf{R}$ Amir Fortifying plants with the essential amino acids lysine and methionine to improve nutritional quality. Plant Biotechnology Journal, 2013; 11(2): 211-222. http://doi.org/10.1111/pbi.12025

43. Escuredo O, González Martín M I, Wells Moncada G, Fischer S and JM Hernández Hierro Amino acid profile of the quinoa (Chenopodium quinoa Willd.) using near infrared spectroscopy and chemometric techniques. Journal of Cereal Science, 2014; 60(1): 67-74. http://doi.org/10.1016/j.jcs.2014.01.016

44. Mota C, Santos M, Mauro R, Samman N, Matos A S, Torres D and I Castanheira Protein content and amino acids profile of pseudocereals. Food Chemistry, 2016; 193: 55-61. http://doi.org/10.1016/j.foodchem.2014.11.043

45. Nowak V, Du J and UR Charrondière Assessment of the nutritional composition of quinoa (Chenopodium quinoa Willd.). Food Chemistry, 2016; 193: 47-54. http://doi.org/10.1016/j.foodchem.2015.02.111

46. Semba R D, Shardell M, Sakr Ashour F A, Moaddel R, Trehan I, Maleta K and MJ Manary Child Stunting is Associated with Low Circulating Essential Amino Acids. EBioMedicine, 2016; 6: 246-252.

http://doi.org/10.1016/j.ebiom.2016.02.030

47. Dodok L, Modhir A A, Buchtová V, Halásová G and I Poláček Importance and utilization of amaranth in food industry. Part 2. Composition of amino acids and fatty acids. Food / Nahrung, 1997; 41(2): 108-110.

http://doi.org/10.1002/food.19970410211

48. Taylor J R N and ML Parker Quinoa. In Pseudo-cereals and Less Common Cereals, 2002; (pp. 93-122). Berlin, Heidelberg: Springer Berlin Heidelberg. http://doi.org/10.1007/978-3-662-09544-7_3

49. Miranda M, Vega-Gálvez A, Martínez E A, López J, Marín R, Aranda M and F Fuentes Influence of contrasting environments on seed composition of two quinoa genotypes: nutritional and functional properties. Chilean Journal of Agricultural Research, 2013; 73(2): 108-116. http://doi.org/10.4067/S071858392013000200004 


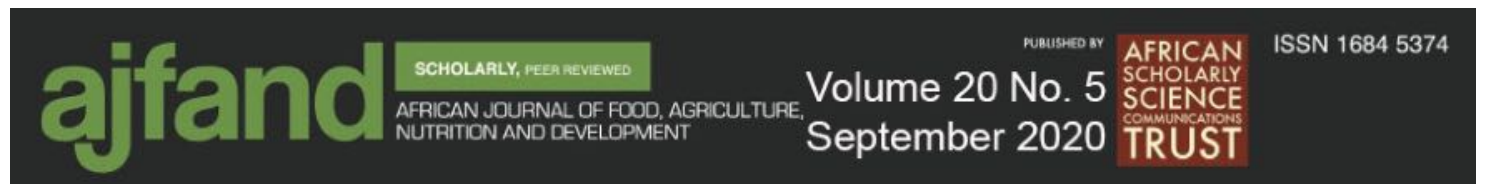

50. Ramolemana G Influence of Soil Chemical Characteristics on the Nutritional Value of Morama (Tylosema esculentum) Bean Seed a Potential Crop in Botswana. Journal of Agricultural Science, 2013; 5(6), 185-189. http://doi.org/10.5539/jas.v5n6p185

51. Adolf $\mathbf{V} \mathbf{I}$, Jacobsen $\mathbf{S} \mathbf{E}$ and Shabala Salt tolerance mechanisms in quinoa (Chenopodium quinoa Willd.). Environmental and Experimental Botany, 2013; 92: 43-54. http://doi.org/10.1016/j.envexpbot.2012.07.004

52. Orshed R M M, Ahman M M R and MAR Ahman Effect of Nitrogen on Seed Yield, Protein Content and Nutrient Uptake of Soybean ( Glycine max L .). Journal of Agriculture and Rural Development, 2008; 6(6): 13-17. 